\title{
Article
}

\section{Powdery mildew species on papaya - a story of confusion and hidden diversity}

\author{
Braun $\mathbf{U}^{1}$, Meeboon $\mathbf{J}^{2}$, Takamatsu $\mathrm{S}^{2}$, Blomquist $\mathrm{C}^{3}$, Fernández Pavía $\mathrm{SP}^{4}$, \\ Rooney-Latham $\mathrm{S}^{3}$, Macedo $\mathrm{DM}^{5}$
}

\begin{abstract}
${ }^{1}$ Martin-Luther-Universität, Institut für Biologie, Institutsbereich Geobotanik und Botanischer Garten, Herbarium, Neuwerk 21, 06099 Halle (Saale), Germany

${ }^{2}$ Mie University, Department of Bioresources, Graduate School, 1577 Kurima-Machiya, Tsu 514-8507, Japan

${ }^{3}$ Plant Pest Diagnostics Branch, California Department of Food \& Agriculture, 3294 Meadowview Road, Sacramento, CA 95832-1448, U.S.A.

${ }^{4}$ Laboratorio de Patología Vegetal, Instituto de Investigaciones Agropecuarias y Forestales, Universidad Michoacana de San Nicolás de Hidalgo, Km. 9.5 Carretera Morelia-Zinapécuaro, Tarímbaro, Michoacán CP 58880, México

${ }^{5}$ Universidade Federal de Viçosa (UFV), Departemento de Fitopatologia, CEP 36570-000, Viçosa, MG, Brazil
\end{abstract}

Braun U, Meeboon J, Takamatsu S, Blomquist C, Fernández Pavía SP, Rooney-Latham S, Macedo DM 2017 - Powdery mildew species on papaya - a story of confusion and hidden diversity. Mycosphere 8(9), 1403-1423, Doi 10.5943/mycosphere/8/9/7

\begin{abstract}
Carica papaya and other species of the genus Carica are hosts of numerous powdery mildews belonging to various genera, including some records that are probably classifiable as accidental infections. Using morphological and phylogenetic analyses, five different Erysiphe species were identified on papaya, viz. Erysiphe caricae, E. caricae-papayae sp. nov., Erysiphe diffusa (= Oidium caricae), E. fallax sp. nov., and E. necator. The history of the name Oidium caricae and its misapplication to more than one species of powdery mildews is discussed under Erysiphe diffusa, to which $O$. caricae is assigned as a heterotypic synonym. Sphaerotheca caricaepapayae is synonymized with Podosphaera xanthii. Podosphaera caricicola comb. nov and additional powdery mildew species occurring on papaya are also described. A key to the papaya powdery mildew species that are considered is provided.
\end{abstract}

Key words - Carica papaya - Erysiphales - Erysiphe - molecular - Podosphaera - phylogeny taxonomy

\section{Introduction}

Papaya (Carica papaya) is an important fruit tree cultivated in most tropical countries. The native distribution of papaya ranges from southern Mexico to Costa Rica (Cavalho 2013). Powdery mildews are important fungal diseases on many different crops and several powdery mildew species have been described on papaya. Oidium caricae, introduced by Noack (1898), was the first name given to a powdery mildew based on material collected in Brazil. The original description of this species was brief and incomplete, which led to this name being misapplied to different species of papaya powdery mildew worldwide. Braun (1987) applied this name to a papaya powdery mildew with catenescent conidia, containing fibrosin bodies and reduced it to synonymy with Sphaerotheca caricae-papayae. When Liberato et al. (2004) re-examined type material of $O$. 
caricae, deposited at Kew (K(M)102465), it was nearly exhausted. Fortunately, H.J. Boesewinkel, who had previously examined and annotated the specimen, described a powdery mildew with multilobed hyphal appressoria and cylindrical conidia, 37-47 $\times 10-15 \mu \mathrm{m}$, formed singly (Boesewinkel 1982b). Based on Boesewinkel's observations, O. caricae belongs to the genus Erysiphe (= Pseudoidium), and was accordingly epitypified by Liberato et al. (2004) with a new Brazilian collection deposited as VIC 26556.

Erysiphe caricae U. Braun \& Bolay (in Bolay 2005) was described on the basis of the asexual and sexual morph (chasmothecia) found in Switzerland on Vasconcellea $\times$ heilbornii ( $\equiv$ Carica $\times$ heilbornii, $=$ Carica $\times$ pentagona $)$. The striking morphological similarities between the asexual morphs of Erysiphe caricae and Oidium caricae, led to the two species being synonymized by Bolay (2005). Braun \& Cook (2012) reallocated Oidium caricae to Pseudoidium Y.S. Paul. Previously many papaya powdery mildews have been indiscriminately referred to as Oidium caricae. Most were insufficiently examined and described or were simply classified as papaya powdery mildew without any specification (Burchill 1978, Freire \& Viana 2001). Preliminary unpublished studies using molecular analyses of papaya powdery mildews have shown that the European E. caricae and Brazilian $O$. caricae sequences are not identical, suggesting they are distinct species of Erysiphe. These preliminary results imply that the name $O$. caricae has been erroneously used for multiple species of papaya powdery mildew. Records of other papaya powdery mildews, including Podosphaera spp., are also unresolved due to insufficient herbarium material and sequence data. The purpose of this work was to provide a comprehensive taxonomic examination, including ITS sequence analyses, of powdery mildews on this important tropical fruit crop.

\section{Materials \& Methods}

Morphology: Fresh powdery mildew collections were examined in distilled water using an Olympus BX50 microscope. Dried herbarium samples were put into a drop of lactic acid and gently heated before examination. Both fresh and dried samples were stained in aniline blue. Measurements of 30 conidia and other structures were made whenever possible at a magnification of $\times 1000$ and $95 \%$ confidential intervals are given with extreme values in parentheses.

Molecular phylogeny: Whole-cell DNA was extracted from mycelia on leaves using the chelex method (Walsh et al. 1991) as described by Hirata \& Takamatsu (1996). For the sample collected in Thailand (MUMH1853), separate sequences were obtained from mycelia taken from fruits and leaves. For the California and Hawaii samples, DNA was extracted from mycelium using the DNA plant mini kit (Qiagen, Carlsbad, California). The rDNA internal transcribed spacer (ITS) regions were amplified by polymerase chain reaction (PCR) using the respective primer pairs: PM5 (Takamatsu \& Kano 2001)/NLP2 (Mori et al. 2000) for 3'-half of ITS and 28S rDNA, and ITS5/PM6 (Takamatsu \& Kano 2001) for 5'-half of ITS. KOD FX Neo DNA polymerase (Toyobo, Japan) was used in the PCR according to the manufacturer's protocol. For California and Hawaii samples, Takara Premix Ex Taq ${ }^{\mathrm{TM}}$ DNA Polymerase (Mountain View, CA) was used. Most amplicons were sent to Solgent Co. Ltd. (Daejeon, South Korea) for direct sequencing using primers PM5 and NLP2 for the PM5/NLP2 fragment and PM6 for the ITS5/PM6 fragment. The California and Hawaii amplicons were sent to GENEWIZ in San Francisco, CA (USA). New sequences determined in this study were deposited in the DNA Data Bank of Japan (DDBJ) under the accession numbers LC228607-LC228619. These sequences were aligned with other related sequences retrieved from DNA databases using MUSCLE (Edgar 2004) implemented in MEGA6 (Tamura et al. 2013). Alignments were further manually refined using the MEGA6 program and were deposited in TreeBASE (http://www.treebase.org/) under the accession number S20817. Phylogenetic trees were obtained from the data using the maximum parsimony (MP) and maximum likelihood (ML) methods. MP analysis was performed in PAUP 4.0a152 (Swofford 2002) with heuristic search option using the tree bisection reconnection (TBR) algorithm with 100 random sequence additions to find the global optimum tree. All sites were treated as unordered and unweighted, with gaps treated as missing data. The strength of internal branches of the resulting 
trees was tested with bootstrap (BS) analysis using 1000 replications with the step-wise addition option set as simple (Felsenstein 1985). Tree scores, including tree length, consistency index (CI), retention index (RI), and rescaled consistency index (RC), were also calculated. The ML analysis was done using raxmlGUI (Silvestro \& Michalak 2012), under a GTRGAMMA model. The BS supports and trees were obtained by running rapid bootstrap analysis of 1000 pseudo-replicates followed by a search for the tree with the highest likelihood.

\section{Results}

\section{Phylogenetic analyses}

New ITS sequences were obtained for eight Erysiphe samples on Carica papaya in this study. These sequences were analyzed with three other Erysiphe sequences deposited in GenBank. The data set consisted of 62 sequences and 608 characters, of which 213 (35.0\%) characters were variable and $130(21.4 \%)$ characters were informative for parsimony analysis. A total of $2.4 \times 10^{4}$ equally parsimonious trees with 578 steps were constructed by the MP analysis. Topologies were nearly consistent among the trees except for branching orders of the terminal branches and branch length. A typical tree is shown in Fig. 1. Since the maximum likelihood analysis generated nearly the same tree topology as the MP analysis, only BS supports are shown. Eleven sequences from samples on Carica papaya were included in this analysis. ITS sequence GU358452, reported by Tsay et al. (2011) was identical to those of E. diffusa (AB078800, AB078806, AB078813) and differed only by two nucleotides $(99.6 \%$ similarity) from the sequence of "Oidium caricae" collected in Brazil (MF616622). Two sequences from papaya collected in North America (Mexico and USA) were identical and formed a distinct clade with BS supports of 99\% (MP) and 100\% (ML). "O. caricae" and the North American samples differed by 9 nucleotides (98.5\%). The ITS sequences from five samples collected in Thailand were identical and also matched Erysiphe aquilegiae (AB015929) and Erysiphe euphorbiae (LC010073). These sequences differed by only one base from GU358451 deposited as "Oidium neolycopersici" from Taiwan (Tsay et al. 2011) and were members of the Erysiphe aquilegiae clade (Takamatsu et al. 2015). A sequence named Erysiphe caricae that was collected in Ukraine (LC009901) was phylogenetically distant from other Erysiphe spp. on papaya.

A BLAST query of an ITS sequence obtained from a collection in Hawaii matched with $100 \%$ identity to a sequence of Erysiphe necator (AF011325), the pathogen which causes powdery mildew of grapevine. Additional sequences of E. necator from grapevine obtained from GenBank and an ITS sequence from a specimen on Caryocar brasiliense (Caryocaraceae) collected in Brazil were used to construct a phylogenetic comparison with the Hawaiian isolate. The data set consisted of 17 sequences and 568 characters, of which 91 (16\%) characters were variable and 23 (4\%) characters were informative for parsimony analysis. Parsimony analysis generated nearly two million equally parsimonious trees with 100 steps. All these trees were identical in topology and differed only in branch lengths. One tree is represented here (Fig. 7). The sequences from both Carica papaya and Caryocar brasiliense belonged to the same clade as Erysiphe necator and are undoubtedly conspecific.

Four powdery mildew specimens collected in this study were shown to be in the Podosphaera group, based on ITS sequence analysis. Two specimens were from the US and two were from Thailand. These ITS sequences were analyzed phylogenetically with other Podosphaera sequences retrieved from GenBank. Cystotheca lanestris and Cy. wrightii were used as outgroup taxa. The data set consisted of 39 sequences and 494 characters, of which 145 (29.4\%) characters were variable and $110(22.3 \%)$ characters were informative for parsimony analysis. Parsimony analysis generated two equally parsimonious trees with 290 steps. A tree with higher likelihood value is shown in Fig. 8. Sequence GU358450 from Taiwan belonged to the clade of Podosphaera xanthii. The four sequences from this study were identical and form a separate clade with strong BS supports (MP $=85 \%, \mathrm{ML}=97 \%$ ). This clade belongs to subsect. Sphaerotheca in Podosphaera sect. Sphaerotheca. 


\section{Multiple taxa of Erysiphe hidden within "Oidium caricae"}

Asexual morphs found on papaya forming lobed hyphal appressoria and solitary conidia had been previously referred to as Oidium caricae. Initial molecular analyses cast doubts upon whether these collections represent a single taxon (Tsay et al. 2011, Takamatsu et al. 2015). In addition, Pseudoidium asexual morphs on papaya that were sequenced did not cluster together in our phylogenetic trees, suggesting that several Erysiphe species cause papaya powdery mildew. These results led to a more detailed examination of this complex of species. The molecular analysis of Oidium caricae material from Brazil, close to the region of the location of epitype material designated by Liberato et al. (2004), was the key to distinguishing $O$. caricae from other papaya powdery mildews in the Erysiphe group. New samples were collected and the sequences were obtained from Robert Barreto's working group in Viçosa, Brazil. Based on the present phylogenetic results, the following Erysiphe spp. have been identified on papaya.

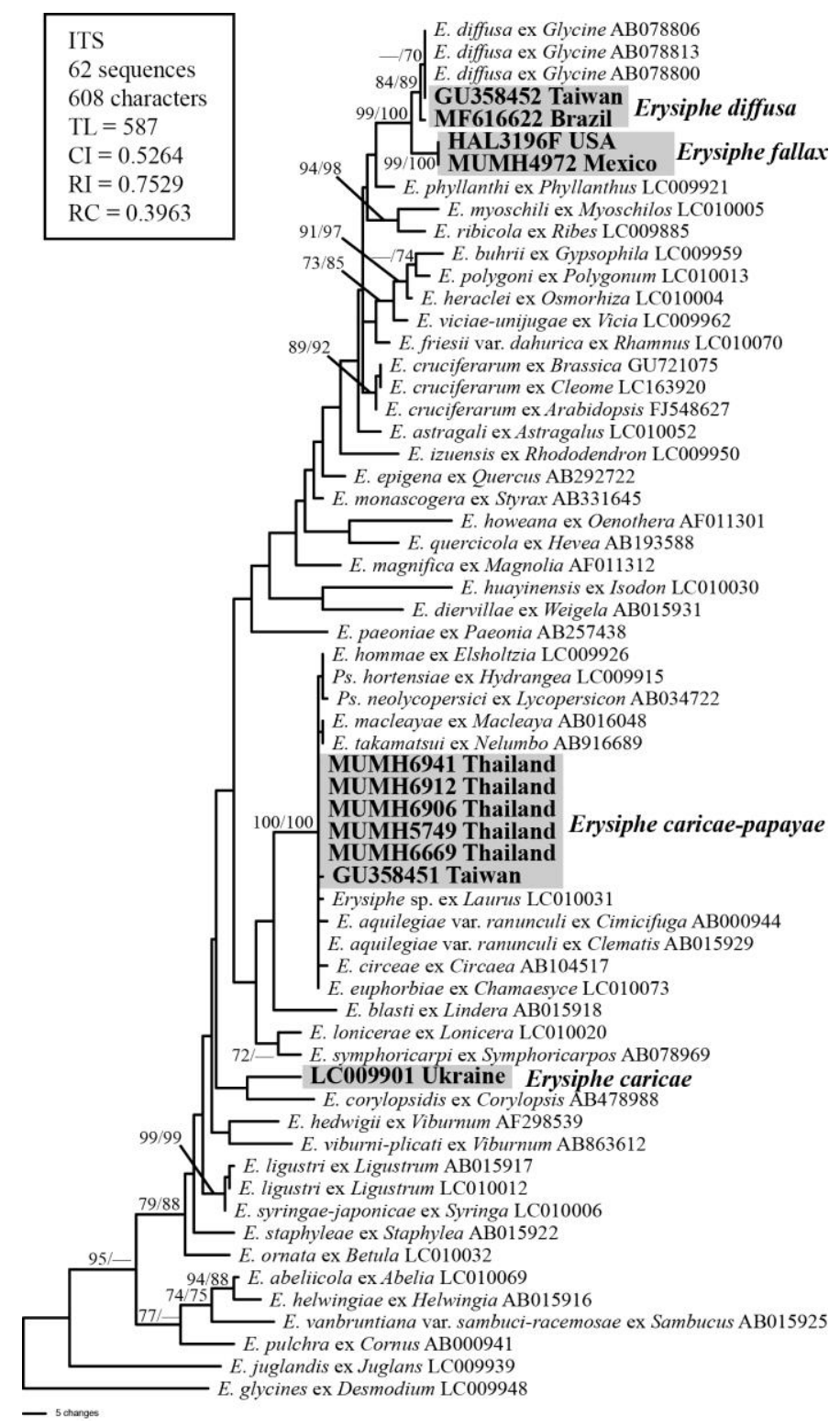

Figure 1 - Phylogenetic analysis of Erysiphe species on Carica papaya was based on combined DNA sequences of internal transcribed spacer (ITS) region. This is a representative tree of the $2.4 \times$ $10^{4}$ equally parsimonious trees with 578 steps, which were found using a heuristic search. Horizontal branch lengths are proportional to the number of substitutions that were inferred to have occurred along a particular branch of the tree. BS $(\geq 70 \%)$ values by the maximum parsimony (MP) and maximum likelihood (ML) methods were shown on the respective branches. 


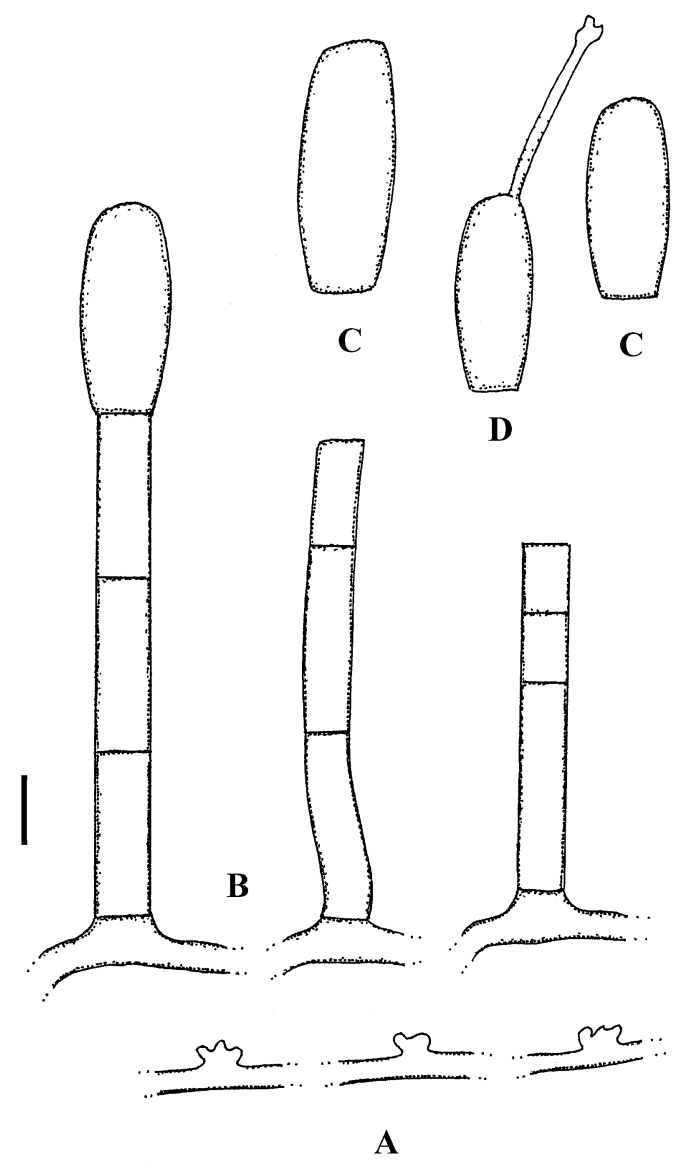

(1) Erysiphe caricae U. Braun \& Bolay, Cryptog. Helv. 20: 46, 2005.

Fig. 2

Misapplied name: Oidium caricae auct. (sensu Bolay 2005, Braun \& Cook 2012).

Illustrations: Bolay (2005: 46-47, figs 18-

19), Braun \& Cook (2012: 369, fig. 412).

Facesoffungi number: FoF 03788

Morphology of the asexual morph of $E$. caricae: Mycelium on leaves, amphigenous, also on petioles, effuse or in patches, white, thin to dense and felted; hyphae 4-8 $\mu \mathrm{m}$ wide, hyaline, thin-walled, smooth; hyphal appressoria solitary, occasionally in opposite pairs, nipple-shaped to moderately lobed, 3-7 $\mu \mathrm{m}$ diam; conidiophores arising from superficial hyphae, from the upper part of the mother cell, erect, up to about $90 \mu \mathrm{m}$ long (without conidia), foot-cells (20-)25-55 $\times$ 6-9 $\mu \mathrm{m}$, usually straight, occasionally somewhat curved or slightly sinuous, followed by 1-2 shorter cells or second cell about as long as the foot-cell or even slightly longer, 12-30 $\mu \mathrm{m}$ long. Conidia solitary, ellipsoid-ovoid to cylindrical, $(25-) 30-50(-60) \times 12-23(-25) \mu \mathrm{m}$, germ tubes perihilar, short to moderately long, with terminal lobed appressoria.

Figure 2 - Erysiphe caricae on Carica papaya. A-D HAL 1819 F. A Hyphal appressoria. B Conidiophores. C Conidia. D Conidium with germ tube. Bar $=10 \mu \mathrm{m}$.

Description of the sexual morph (chasmothecia): see Bolay (2005: 46) and Braun \& Cook (2012: 369).

Material examined (asexual morph and chasmothecia) - Switzerland, VS, Conthey, Les Fougères, on Vasconcellea $\times$ heilbornii (三Carica $\times$ heilbornii, = Carica $\times$ pentagona), 28 November 1989, A. Bolay (holotype HAL 3200 F; isotype G00298363). Ukraine, Kiev, University, O.V. Fomin Botanical Garden, on Carica papaya, 30 March. 2004, V. Kovalchuk (HAL 1819 F).

Notes - Erysiphe caricae was introduced by Braun \& Bolay (in Bolay 2005), based on European material collected in Switzerland. This was the first Erysiphe species on papaya based on holomorph material that included mature chasmothecia. Additional specimens with ascomata were collected in Ukraine and included in molecular sequence analyses in Takamatsu et al. (2015), which confirmed the status of $E$. caricae as a distinct species, clustering in a different clade that is distant from other Erysiphe spp. on papaya (Fig. 1). The asexual morphs of E. caricae and Oidium caricae are nearly indistinguishable by morphology, which explains the earlier treatment of $O$. caricae as a synonym of Erysiphe caricae in Braun \& Cook (2012). However, our phylogenetic analyses clearly showed that E. caricae, which is, to the best of our knowledge, only known from Europe, and $O$. caricae, described from Brazil, are two unrelated species. A specimen collected in Germany (Brandenburg, Oranienburg, Oranienburger Schloßgarten, on Carica papaya, 26 August 2009, V. Kummer, only asexual morph, HAL 3190 F) seems to belong to Erysiphe caricae, but has not yet been confirmed by sequence analyses.

(2) Erysiphe caricae-papayae Meeboon \& S. Takam., sp. nov.

Fig. 3, 4 MycoBank MB822384; Facesoffungi number: FoF 03789

Etymology - Epithet derived from the host species, Carica papaya. 
Mycelium on leaves, amphigenous, also on petioles, forming thin to dense white patches or effuse, evanescent to persistent; hyphae superficial, branched, 2-7 $\mu \mathrm{m}$ wide, septate, hyaline, thinwalled, smooth; hyphal appressoria solitary or in opposite pairs, nipple-shaped or slightly lobed to multilobed, 3-7 $\mu \mathrm{m}$ diam. Conidiophores arising from superficial hyphae, on the upper surface of the mother cell, erect, $60-150 \mu \mathrm{m}$ long (without conidia), foot-cells $20-70 \times 5-9 \mu \mathrm{m}$, cylindrical, usually straight, occasionally somewhat curved to sinuous, followed by $1-3(-4)$ cells, $8-50 \times 8-12$ $\mu \mathrm{m}$, mostly shorter than the foot-cell, second cell occasionally about as long as the foot-cell or even longer, width of the following cells often gradually increasing towards the end of the conidiophores, somewhat wider than the foot-cells. Conidia solitary, ellipsoid-ovoid, subcylindrical to almost cylindrical, $25-40 \times 14-18 \mu \mathrm{m}$, apex rounded to subtruncate, base rounded to truncate. Germination not observed. Chasmothecia scattered to gregarious, $103-185 \mu \mathrm{m}$ diam; peridium cells irregularly polygonal, 10-20 $\mu \mathrm{m}$ diam; appendages about 4-10(-15), arising between base and equator, horizontally spread, simple, occasionally 1-2 times irregularly branched, coarse and straight, flexuous or slightly sinuous-geniculate, 140-325 long and 6-8 $\mu \mathrm{m}$ wide, septate, brown below and paler towards the apex or brown throughout when mature, wall thickened towards the base, 2.3-3.5 $\mu \mathrm{m}$, smooth, sometimes faintly rough; asci 4-9, ellipsoid-obovoid, clavate-saccate, 35-60 × 27-36 $\mu \mathrm{m}$, wall thick, 2.5-4 $\mu \mathrm{m}$, sessile or short-stalked, (2-)3-5(-6)-spored; ascospores

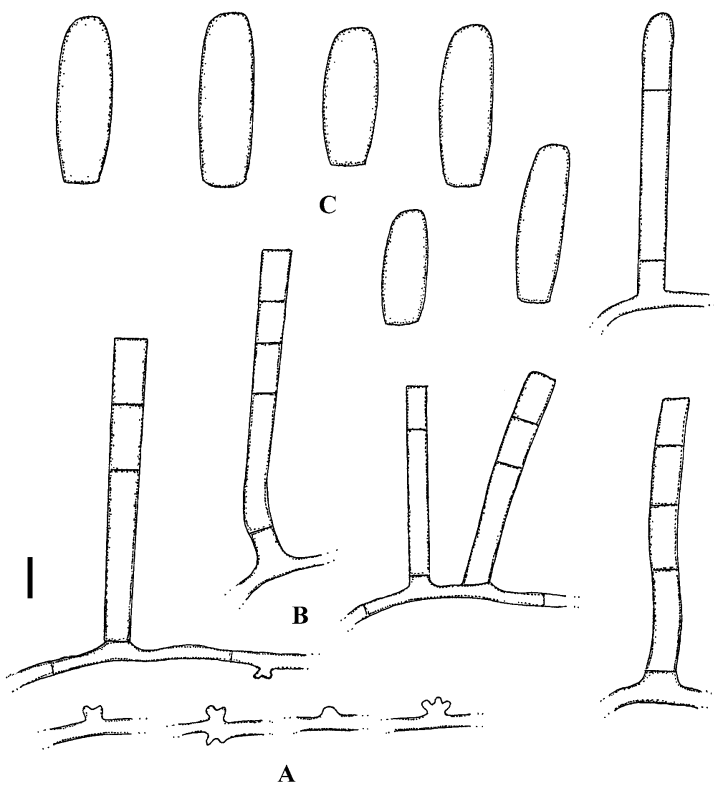
ellipsoid-ovoid, 11-24 × 8-13 $\mu \mathrm{m}$, hyaline or faintly yellowish.

Material examined - Thailand, Chiang Rai, on Carica papaya (Caricaceae), 22 November 2013, J. Meeboon (holotype TSU-MUMH5749), GenBank number (ITS): LC228610; Chiang Mai, 19 January 2016, J. Meeboon (TSU-MUMH 6669, HAL 3191 F), GenBank number (ITS): LC228611; Chiang Rai, 24 December 2000, S. Takamatsu (TSU-MUMH 3383, HAL 3192 F), mixed infection together with Podosphaera sp.; Chiang Rai, 29 December 2016, J. Meeboon \& S. Takamatsu (TSU-MUMH 6906, HAL 3193 F), GenBank number (ITS): LC228612; Chiang Rai, 30 December 2016, J. Meeboon \& S. Takamatsu (TSU-MUMH 6912, HAL 3194 F), GenBank number (ITS+28S): LC228613.

Figure 3 - Erysiphe caricae-papayae sp. nov. on Carica papaya. A-C HAL 3194 F. A Hyphal apppressoria. B Conidiophores. C Conidia. Bar $=10 \mu \mathrm{m}$.

Notes - Tsay et al. (2011) examined asexual powdery mildews on papaya in Taiwan, including molecular sequence analyses, and identified one of them as Oidium neolycopersici L. Kiss. In the course of the present study, additional sequences obtained from papaya powdery mildews collected in Thailand were found to be identical with the Taiwanese sequence (see Fig. 1). The sexual morph (chasmothecia) was found in one of the collections. Pseudoidium neolycopersici (L. Kiss) L. Kiss phylogenetically belongs to a complex clade, classified as "Erysiphe aquilegiae clade" in Takamatsu et al. (2015). This clade is composed of closely allied Erysiphe species, including Pseudoidium neolycopersici, but has insufficient resolution within the ITS region. This phenomenon is not uncommon in other complexes of closely allied ascomycete species including the Cercospora apii Fresen. complex (Groenewald et al. 2012) and species of Cladosporium Link (Bensch et al. 2012). Further phylogenetic examinations using sequences from additional genes are necessary for trees with better resolutions. The identification of these powdery mildew collections on papaya as "Oidium neolycopersici" by Tsay et al. (2011) is not tenable. Conidiophores and conidia of the species in the E. aquilegiae complex are rather uniform, with few characters that can 
be morphologically differentiated. However, the sexual fruiting bodies found on papaya in Thailand allow more precise comparisons and differentiations. The chasmothecia found on papaya in Thailand are much larger than Erysiphe aquilegiae fruiting bodies (103-185 $\mu \mathrm{m}$ diam vs. (65-)75$115(-125) \mu \mathrm{m}$ in E. aquilegiae), with fewer appendages 4-10(-15) per chasmothecium (vs. numerous, (4-)10-30(-50) in E. aquilegiae), thicker-walled towards the base of the appendage (wall 2.3-3.5 $\mu \mathrm{m}$ wide vs. $1-2(-2.5) \mu \mathrm{m}$ wide in E. aquilegiae), and contain asci that are thickerwalled, (2.5-)3.5-4 $\mu \mathrm{m}$ vs. 1-2.5(-3) in E. aquilegiae. Amongst other species of Erysiphe sect. Erysiphe, E. malvae Heluta is morphologically comparable with E. caricae-papayae, but this species differs in having frequently branched, only 0-1-septate chasmothecial appendages (Braun \& Cook 2012). Based on the genotypic and phenotypic results, the present Erysiphe species on papaya in Thailand is undoubtedly a distinct species.

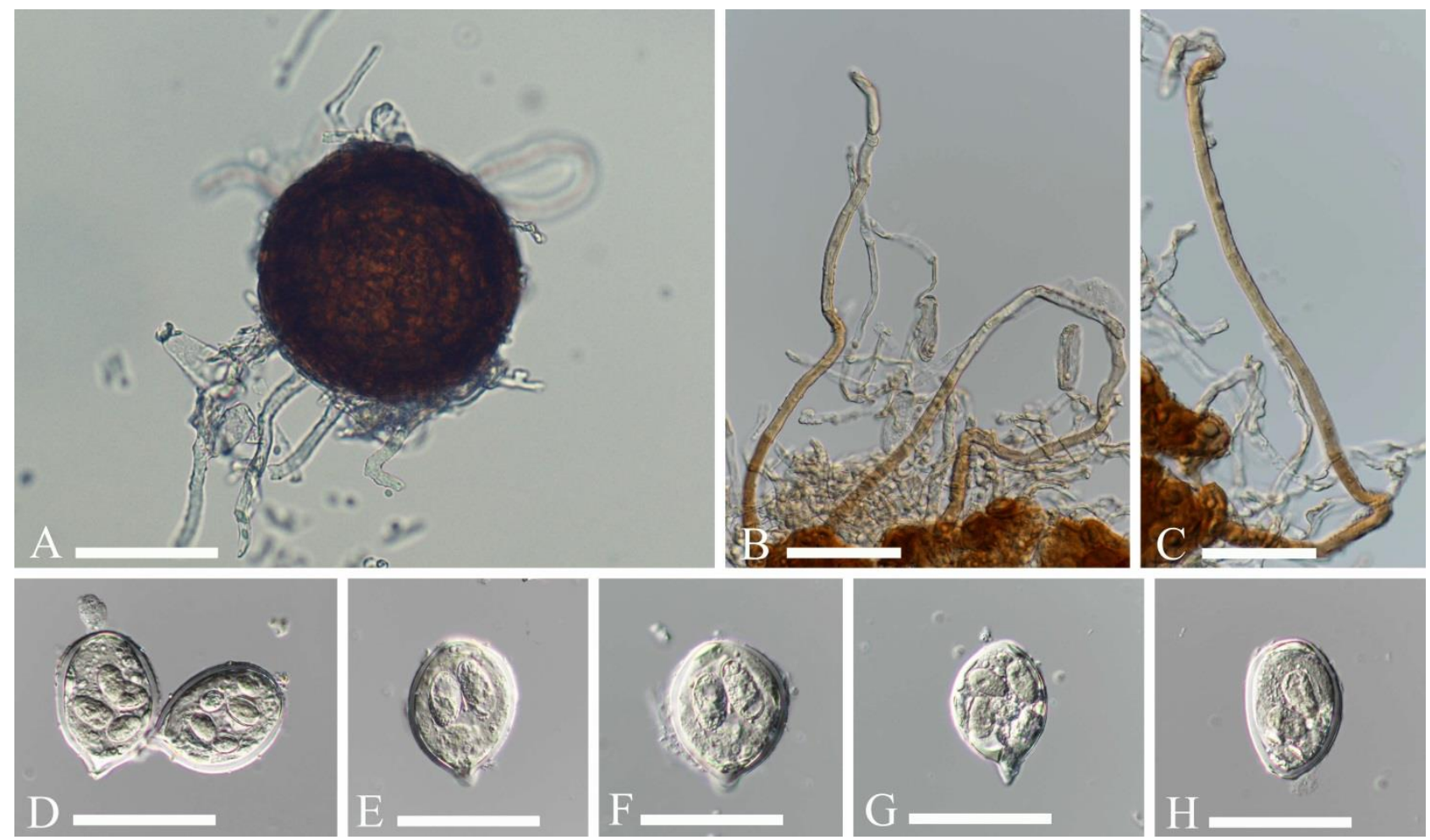

Figure 4 - Erysiphe caricae-papayae sp. nov. on Carica papaya. A-H TSU-MUMH5749. A Chasmothecium. B, C Appendages. D-H Asci. - Bars $=50 \mu \mathrm{m}$.

(3) Erysiphe diffusa (Cooke \& Peck) U. Braun \& S. Takam., Schlechtendalia 4: 7, 2000.

Fig. 5 三 Microsphaera diffusa Cooke \& Peck, J. Bot. 10: 13, 1873.

= Oidium caricae F. Noack, Bol. Inst. Agron. Estado São Paulo 9(2): 81, 1898, syn. nov.

三Pseudoidium caricae (F. Noack) U. Braun \& R.T.A. Cook, CBS Biodiversity Series 11: 369, 2012.

Facesoffungi number: FoF 03790

Morphology of the asexual morph found on papaya (based on VIC 26556, 44310): Mycelium amphigenous, thin, inconspicuous to conspicuous, persistent, forming dense white patches, confluent; hyphae branched, 4-8 $\mu \mathrm{m}$ wide, hyaline, thin-walled, smooth, septate; hyphal appressoria slightly lobed to multilobed, solitary or in opposite pairs; conidiophores arising from superficial hyphae, on the upper surface of mother cells, erect, 55-100 $\times$ 9-12.5 $\mu \mathrm{m}$ (without conidia), foot-cells straight or occasionally somewhat curved or flexuous, $20-45 \mu \mathrm{m}$ long, followed by 1-2(-3) cells, mostly shorter or about as long as the foot-cell; conidia formed singly, ellipsoidovoid to cylindrical, 25-60 $\times(10-) 13-20(-25) \mu \mathrm{m}$, both ends rounded to subtruncate, germ tubes perihilar, short to two times as long as the conidial length, simple or occasionally forked, terminal appressoria unlobed to lobed. 
Material examined - Brazil, Minas Gerais, Viçosa, on Carica papaya, 29 May 2003, J.R. Liberato (epitype of Oidium caricae, designated by Liberato et al. 2004, VIC 26556); Minas Gerais, Viçosa, on Carica papaya, 27 July 2016, D.M. Macedo (VIC 44310), GenBank number (ITS): MF616622.

Notes - Tsay et al. (2011) reported Erysiphe diffusa on papaya from Taiwan and confirmed the identification by means of molecular sequence analyses. ITS sequences obtained from papaya were $100 \%$ match to sequences from E. diffusa on Glycine spp., suggesting that papaya may be another host of $E$. diffusa. This is the first report of $E$. diffusa on a host other than a legume. Since the morphology of the asexual morph found on papaya was not described in detail in Tsay et al. (2011), it is unknown if isolates from the two hosts are morphologically similar. A sequence retrieved from representative material of Oidium caricae from Brazil is $99.6 \%$ identical (two bp difference) to $E$. diffusa sequences, suggesting that a single species is involved (Fig. 1). The Brazilian sequence was not retrieved from the scanty epitype material but from a sample recollected at the epitype locality in 2016 by M. de Macedo. Therefore, we consider that $O$. caricae is synonymous with E. diffusa. The name Oidium caricae has been often used incorrectly for papaya powdery mildews that were not related to O. caricae. Braun (1987) erroneously reduced the
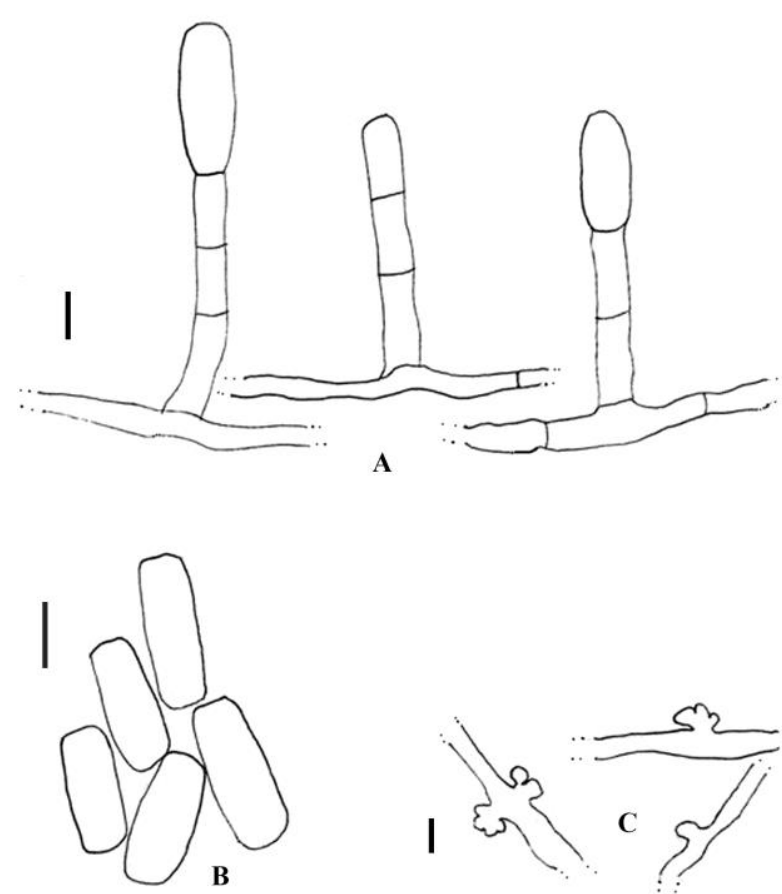
name $O$. caricae to synonymy with Sphaerotheca caricae-papayae, which was influenced by Noack's misleading original description, primarily the given conidial size of only $23-25 \times 14.5-20$ $\mu \mathrm{m}$. Yen's (1966) treatment of $O$. caricae may also be a different species (see Liberato et al. 2004). Yen (l.c.) mentioned that he had examined material deposited at PC, which was collected by Noack in Brazil, and a specimen from Kenya deposited at IMI that he referred to as $O$. caricae, but he classified the powdery mildew concerned as "Euoidium type" suggesting that the conidia were catenescent. However, O. caricae represents a Pseudoidium characterized by having lobed hyphal appressoria and long \pm cylindrical conidia formed singly, which could be confirmed by the examination of type material (Brazil, Campinas, on Carica papaya, Nov. 1897, F. Noack, holotype K(M)102465, exhausted material; see Boesewinkel 1982b). The type material deposited at $\mathrm{K}$ was annotated by the latter author accordingly.

Figure 5 - Erysiphe diffusa (= Oidium caricae) on Carica papaya. A-C VIC 44310. A Conidiophores. B Conidia. C Hyphal appressoria. - Bars, $A=10 \mu \mathrm{m}, \mathrm{B}=20 \mu \mathrm{m}, \mathrm{C}=5 \mu \mathrm{m}$.

Unfortunately, the type material is now almost devoid of any fructification. Therefore, Liberato et al. (2004) designated an epitype collected in Brazil. Boesewinkel (1982a,b) examined papaya powdery mildew found in New Zealand and provided a detailed survey and discussion. Boesewinkel (1982b) carried out inoculation experiments and was able to inoculate Erysiphe cruciferarum Opiz ex L. Junell from radish to papaya. Therefore, he proposed to reduce $O$. caricae to synonymy with E. cruciferarum, and several authors followed Boesewinkel's (1.c.) taxonomic conclusion and used E. cruciferarum for Pseudoidium anamorphs on papaya (e.g., Gorter 1993, Crous et al. 2000, South Africa; Teixeira et al. 2007; Cunningham \& Nelson 2012, Hawaii). However, this "identification" was based only on papaya powdery mildew collected in New Zealand and cannot be simply applied to $O$. caricae described from Brazil. Furthermore, there are several morphologically very similar asexual Erysiphe morphs on papaya worldwide. Since 
detailed descriptions and sequences of the collections from Hawaii, New Zealand as well as South Africa are not available, these records cannot be properly identified currently. However, sequence analyses of material of $O$. caricae, collected in Brazil and representative for this species, showed that the Brazilian papaya powdery mildew does not cluster with E. cruciferarum sequences but matches $E$. diffusa (Fig. 1). The name $O$. caricae has been applied to papaya powdery mildews worldwide (Fossard 1969, Amano 1986), but due to the widespread misapplication of this name explained above and the occurrence of different Erysiphe species with morphologically similar asexual morphs on papaya, most of these records cannot be assigned to names with any confidence.

Erysiphe diffusa is common in North America and known from South America (Amano 1986, Braun \& Cook 2012). Fu et al. (2015) recently recorded E. diffusa on Wisteria sinensis in China. A first report of Erysiphe on Glycine dates back to Wahl (1921) who listed Erysiphe polygoni on this host, followed by Lehman (1931) who also identified this powdery mildew as $E$. polygoni. Later, Lehman (1947) re-examined it and identified it as Microsphaera sp. The first

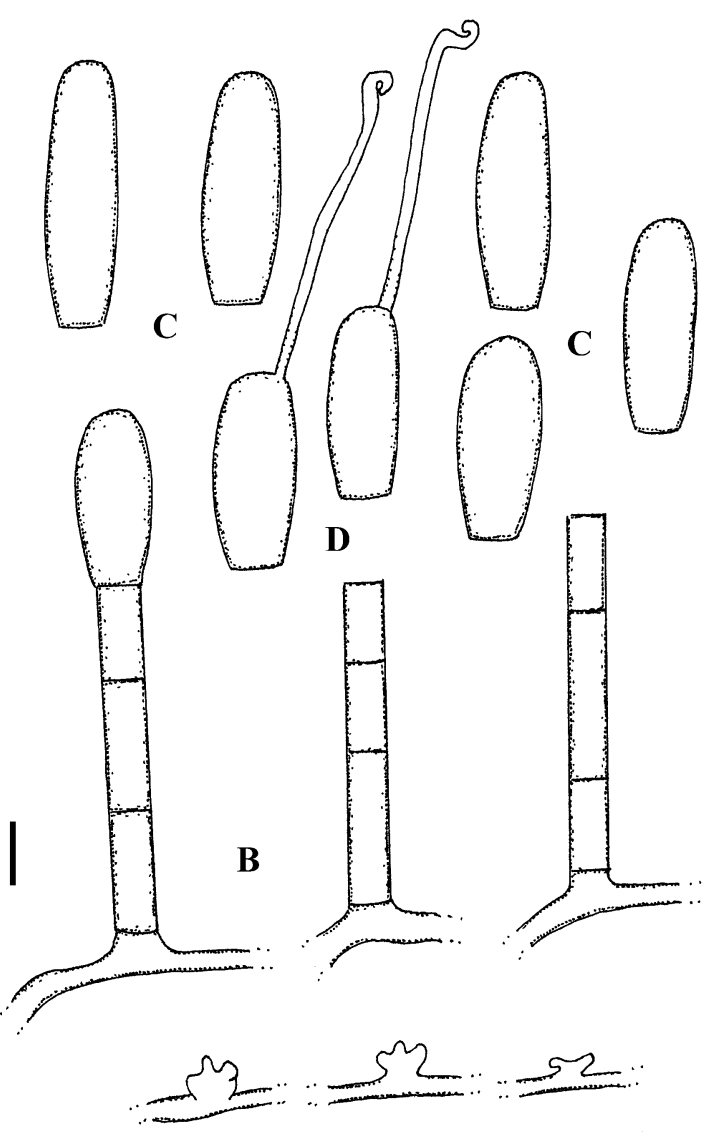

A published reports of the sexual morph of the Glycine powdery mildew seem to refer to Paxton \& Rogers (1974) and McLaughlin et al. (1977). Mignucci \& Chambertain (1978) carried out detailed inoculation experiments with $E$. diffusa on Glycine and numerous other legumes and demonstrated the ability of this powdery mildew to infect various other hosts of the Fabaceae. Desmodium canadense, the type host of $E$. diffusa, was unfortunately not included in these examinations. Nevertheless, all available data suggest that the host range of $E$. diffusa includes more than Glycine spp., on which this species is widespread in North and South America [Brazil, Canada, USA (Basu 1980, Mendes et al. 1998, Braun \& Cook 2012, Takamatsu et al. 2002)]. Outbreaks of powdery mildew infections on Glycine spp. by E. diffusa, accompanied by significant spread of this disease, have recently been reported in Asia (South Korea, northeast India, Japan, Taiwan, Vietnam) and Australia (Queensland) (Takamatsu et al. 2002, Cho \& Shin 2004, McTaggart et al. 2012, Baiswar et al. 2016).

Figure 6 - Erysiphe fallax sp. nov. on Carica papaya. A-D HAL 3194 F. A Hyphal apppressoria. B Conidiophores. C Conidia. D Conidia with germ tubes. Bar $=10 \mu \mathrm{m}$.

(4) Erysiphe fallax C. Blomq., S. Rooney-Latham \& Fernández Pavía, sp. nov.

Fig. 6 MycoBank MB822385; Facesof fungi number: FoF 03791

Etymology: fallax ("deceptive"), referring to the confusion with Oidium caricae and other asexual Erysiphe morphs on papaya.

Sexual morph unknown. Mycelium amphigenous, thin, forming loose to dense white patches or effuse; hyphae branched, 3-8 $\mu \mathrm{m}$ wide, hyaline, thin-walled, smooth, septate; hyphal appressoria slightly to distinctly lobed, 3-8 $\mathrm{mm}$ diam; conidiophores arising from superficial hyphae, on the upper surface of mother cells, erect, 50-100 $\mu \mathrm{m}$ long (without conidia), foot-cells $25-50 \times(6-) 7-9(-10) \mu \mathrm{m}$, cylindrical or subcylindrical, straight, occasionally flexuous, somewhat sinuous, basal septum at the junction with its mother cell or slightly elevated (to $5 \mu \mathrm{m}$ ), 
occasionally constricted at the basal septum (5-6 $\mu \mathrm{m}$ wide), foot-cells followed by 1-3 cells, 10$35(-40) \mu \mathrm{m}$ long, shorter than the foot-cells or about as long as the foot-cells, occasionally even longer; conidia formed singly, ellipsoid, subcylindrical to cylindrical, (30-)35-50 × 13-20 $\mu \mathrm{m}$, apex rounded to subtruncate, base truncate to subtruncate, germ tubes perihilar, short to moderately long, terminal appressoria unlobed to lobed or apex curved-sigmoid (only a few germ tubes naturally developed on leaves have been observed).

Material examined - Mexico, Huamuxtitlan, Mpio. de Huamuxtitlan, Gro., 10 January 2009, Juan Manuel Tovar Pedraza (holotype TSU-MUMH4972), GenBank number (ITS+28S): LC228608. USA, California, Santa Barbara Co., outdoor collection, on Carica papaya, 23 July 2014, H. Scheck (HAL 3196 F), GenBank number (ITS): LC228618; on Carica papaya, cultivar "Maradol", 28 July 2014, H. Scheck (HAL 3197 F); on Carica papaya, cultivar "Solo", 28 July 2014, H. Scheck (HAL 9198 F).

Notes - Amano (1986) listed "Erysiphe communis" on papaya from Mexico. Alvarez (1976) reported Erysiphe polygoni and Oidium caricae from Mexico, followed by Mexican reports of Oidium caricae in Alvarez (1981), Soldaña et al. (1985), Yánez-Morales et al (2009), and Fernández-Pavía et al. (2015). These reports might refer to E. fallax, which is morphologically barely distinguishable from the asexual morph of E. diffusa. Sequences of this papaya powdery mildew (ITS/28S rDNA) from specimens collected in Mexico and the USA are identical and cluster close to sequences of $E$. diffusa (including $O$. caricae from Brazil). However, they cluster with a correlation rate of $98.5 \%$, suggesting that two different species are involved (Fig. 1). Since asexual morphs of Erysiphe spp. on papaya are morphologically similar, reliable identification of E. fallax collections must be confirmed by means of molecular sequence analyses.

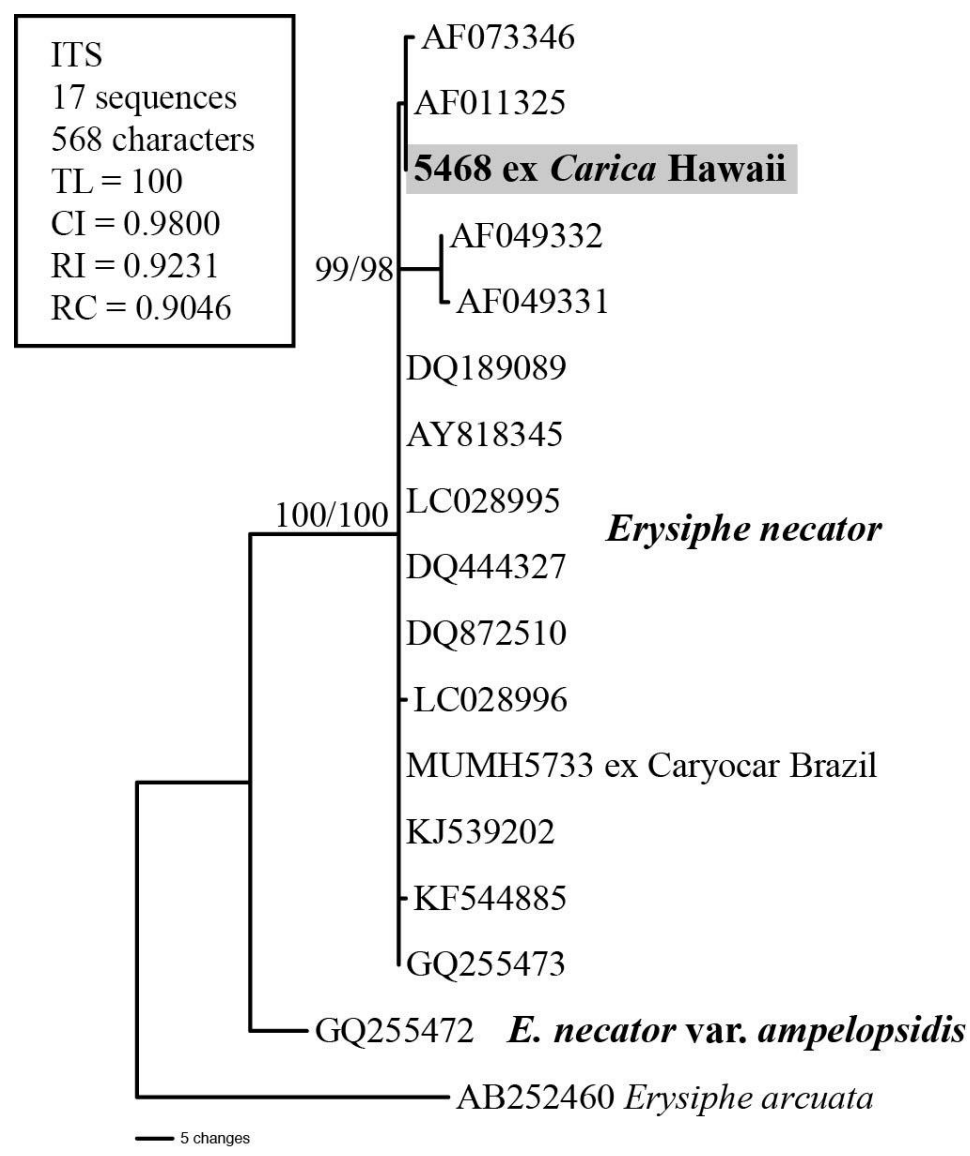

Figure 7 - Phylogenetic analysis of Erysiphe necator on Carica papaya based on combined DNA sequences of internal transcribed spacer (ITS) region. This is one of the nearly two million equally parsimonious trees with 100 steps, which were found using a heuristic search. Horizontal branch lengths are proportional to the number of substitutions that were inferred to have occurred along a particular branch of the tree. BS ( $\geq 70 \%)$ values by the maximum parsimony (MP) and maximum likelihood (ML) methods were shown on the respective branches. 
(5) Erysiphe necator Schwein., Trans. Amer. Philos. Soc. II, 4: 270, 1834.

EUncinula necator (Schwein.) Burrill, in Ellis \& Everh., North Amer. Pyrenomyc.: 15, 1892.

Material examined - USA, Hawaii, Hilo, on Carica papaya, 10 Jan. 2017, Stacey Chun (HAL 3202 F), GenBank number (ITS): LC228619.

Facesoffungi number: FoF 03792

Notes - In the course of the present studies, an asexual morph (Pseudoidium) morphologically agreeing with Erysiphe necator was unexpectedly found on papaya in Hawaii. Results of sequence analyses confirmed this identification and demonstrated the potential ability of this important and widespread Vitis powdery mildew to cause accidental infections on an unrelated host (Fig. 7). However, an unequivocal morphological confirmation was not possible since twisted foot-cells of the conidiophores, which are characteristic for E. necator, were not observed on papaya. Powdery mildew of Carycar sp. (Caryocaraceae) by E. necator (material collected in Brazil in 2004 by J.C. Dianese, TSU-MUMH 5733, GenBank number (ITS): LC228609), identified by molecular sequence analyses, is an additional case of a possible cross-infection of E. necator on an unrelated host. However, the morphology of the Carycar collection could not be proven and the remaining material is insufficient for a detailed analysis. Morphologically, the powdery mildew on Carycar sp. could only be shown to belong to Erysiphe (appressoria lobed, conidia formed singly).

\section{Additional powdery mildew species occurring on papaya}

Podosphaera caricicola (J.M. Yen \& Chin C. Wang) U. Braun \& S. Takam., comb. nov. (sect. Sphaerotheca subsect. Sphaerotheca).

MycoBank MB822386

Basionym: Oidium caricicola J.M. Yen \& Chin C. Wang, Rev. Mycol. 37(3): 133, 1973.

Illustration: Yen \& Wang (1973: 130, fig 3).

Facesoffungi number: FoF 03793

Description of the asexual morph: Mycelium on leaves, forming thin white patches or effuse; hyphae 4-8 $\mu \mathrm{m}$ wide, septate, thin-walled, smooth; hyphal appressoria indistinct to nipple-shaped; conidiophores arising from superficial hyphae, on the upper surface of the mother cell, arising more or less centrally on the mother cell or mostly non-centrally, i.e. towards one end, erect, straight, about 50-100 $\mu \mathrm{m}$ long (without conidia), foot-cells cylindrical, relatively short, 30-50 × 9-13 $\mu \mathrm{m}$, followed by 1-3 shorter cells, about 10-25 $\mu \mathrm{m}$ long, often slightly constricted at the basal septum at the junction with the supporting hypha, 7-8 $\mu \mathrm{m}$ wide; conidia catenescent, ellipsoid-ovoid to doliiform, 25-38 $\times 14-20 \mu \mathrm{m}$, with fibrosin bodies, apex rounded in primary conidia, subtruncate in secondary conidia, base subtruncate, germ tubes long and cylindrical-filiform, continuous to septate, without distinct terminal appressorium.

Holotype: Taiwan, Fengshan, on Carica papaya, 8 Jan. 1973, C.C. Wang, F.S. No. 44 (not preserved).

Lectotype (designated here, MycoBank MBT378320): J.M. Yen \& Chin C. Wang, Rev. Mycol. 37(3): 130, fig. 3, 1973 (original drawing).

Material examined - Thailand, Chiang Rai, on Carica papaya, 20 December 2002, S. Takamatsu (epitype TSU-MUMH 1853, designated here, MycoBank MBT378321), GenBank number (ITS): AB525918, LC228607; duplicate of epitype HAL 3195 F. USA, California, Santa Barbara Co., green house collection, on Carica papaya, 13 May and 19 August 2014, H. Scheck (HAL 3199 F), GenBank number (ITS): LC228616; California, Orange Co., Buena Park, 26 April 2017, M. Del Toro \& L. Kumagai (HAL 3213 F). THAILAND, Chiang Rai, on C. papaya, 24 December 2000, S. Takamatsu (TSU-MUMH 3383, HAL 3192 F).

Notes - Clare (1964) listed a powdery mildew on papaya from Australia, including ascomata, and classified it as a species of Sphaerotheca which is now known as Podosphaera aphanis (Wallr.) U. Braun \& S. Takam. This powdery mildew caused significant damage to papaya and could even kill the young growing tips and infect fruits (Simmonds 1965, Boesewinkle 1982b). Species of the $P$. aphanis complex (subsect. Sphaerotheca) are readily distinguishable from $P$. 
xanthii (subsect. Magnicellulatae) in having chasmothecia with much smaller peridial cells and clear differences in the asexual morphs, including a quite distinct conidial germination pattern (Braun \& Cook 2012). In the course of the present examinations of papaya powdery mildews, two sequences from Thailand and two from the USA, clustering near to P. aphanis and P. fugax (Penz. \& Sacc.) U. Braun \& S. Takam., have been obtained (Fig. 8), which may be Clare's (1964) species detected in Australia. Boesewinkel (1982b) interpreted a record of "Oidium caricae" from Java (van Overeem \& Schwarz 1926) as "Sphaerotheca alchemillae" (now Podosphaera aphanis), which might also be the same papaya powdery mildew. The collections on papaya recently found in Thailand and in the USA have been sequenced and cluster among other species of Podosphaera sect. Sphaerotheca subsect. Sphaerotheca, but they are not identical to P. aphanis, i.e. they are genetically and morphologically distinct. The asexual morph of this taxon on papaya differs morphologically from that of $P$. aphanis and other species of subsect. Sphaerotheca in having much shorter cylindrical conidiophores (30-50 $\mu \mathrm{m}$ long, versus 30-160 $\mu \mathrm{m}$ long) and conidiophores that do not increase in width towards the apex, as they do in P. aphanis. These results suggest that this powdery mildew belongs to an unknown species distinct from $P$. aphanis. The sample from Thailand (TSU-MUMH 3383) proved to be a mixed infection of two powdery mildew species, viz. a Podosphaera sp., morphologically agreeing with the epitype of $P$. caricicola, and a species of Erysiphe with lobed hyphal appressoria and conidia formed singly which seems to belong to Erysiphe caricae-papayae. Attempts to locate the Australian collection with ascomata failed. We prefer to use the name Oidium caricicola for this species by fixing its application via lecto- and epitypification, rather than introducing a new species. Based solely on the morphology of the asexual morphs, the two species of Podosphaera on papaya, P. caricicola and $P$. xanthii (incl. $P$. caricae-papayae) are not easily distinguishable. The conidiophores of $P$. caricicola are unusually short for a species of Podosphaera sect. Sphaerotheca subsect. Sphaerotheca and resemble those of $P$. xanthii belonging in subsect. Magnicellulatae. Conidial germination, ascoma morphology, or molecular sequence analyses are necessary to distinguish these species.

Yen \& Wang (1973) introduced O. caricicola and described nipple-shaped hyphal appressoria, long conidiophores $(80-185 \times 15-18 \mu \mathrm{m}$, including conidial chains) with relatively short cylindrical foot-cells, 30-40 × 11-12 $\mu \mathrm{m}$, and catenescent conidia, 25-33 $\times 16-21 \mu \mathrm{m}$. The presence or absence of fibrosin bodies was not mentioned. Braun \& Cook (2012) interpreted this species as a possible synonym of Podosphaera xanthii based on relatively small conidia formed in chains, since Sphaerotheca caricae-papayae was reduced to synonymy with $P$. xanthii. However, Yen \& Wang (1973) illustrated simple, long germ tubes without any conspicuous terminal appressoria, which conflicts with the interpretation of this species as $P$. xanthii, a species that belongs to Podosphaera sect. Sphaerotheca subsect. Magnicellulatae. Species of the latter subsection were previously referred to as Sphaerotheca fuliginea s. lat., a species complex characterized by having quite distinct, usually short and stout, often even forked lateral germ tubes (Braun \& Cook 2012). Long cylindrical-filiform germ tubes suggest this species belongs to Podosphaera sect. Sphaerotheca subsect. Sphaerotheca (P. aphanis complex). Boesewinkel (1982b) considered $O$. caricicola a potential synonym of "Erysiphe cichoracearum" which is questionable, since the conidial size and the described germ tubes are not characteristic of a Golovinomyces. Furthermore, infections on papaya are rather to be expected by the plurivorous $G$. orontii, which is characterized by having conidiophore foot-cells that are often curved at the base. Since type material of $O$. caricicola could not be located and was likely not preserved, Liberato et al. (2004) classified this species as a doubtful, unclear taxon, either belonging to Golovinomyces or Podosphaera. A solution to this problem would be possible either by tracing and examining the holotype or by lectotypification of $O$. caricicola complemented by epitypification. Since the holotype of $O$. caricicola could not be traced and is possibly not maintained, we prefer to take the latter path. The original, detailed drawing published by Yen \& Wang (1973) agrees very well with epitype material from Thailand. This illustration is the only thing remaining of the original material for this species and is therefore designated as lectotype (according to ICN, Art. 9.2, 9.3, 9.12). 


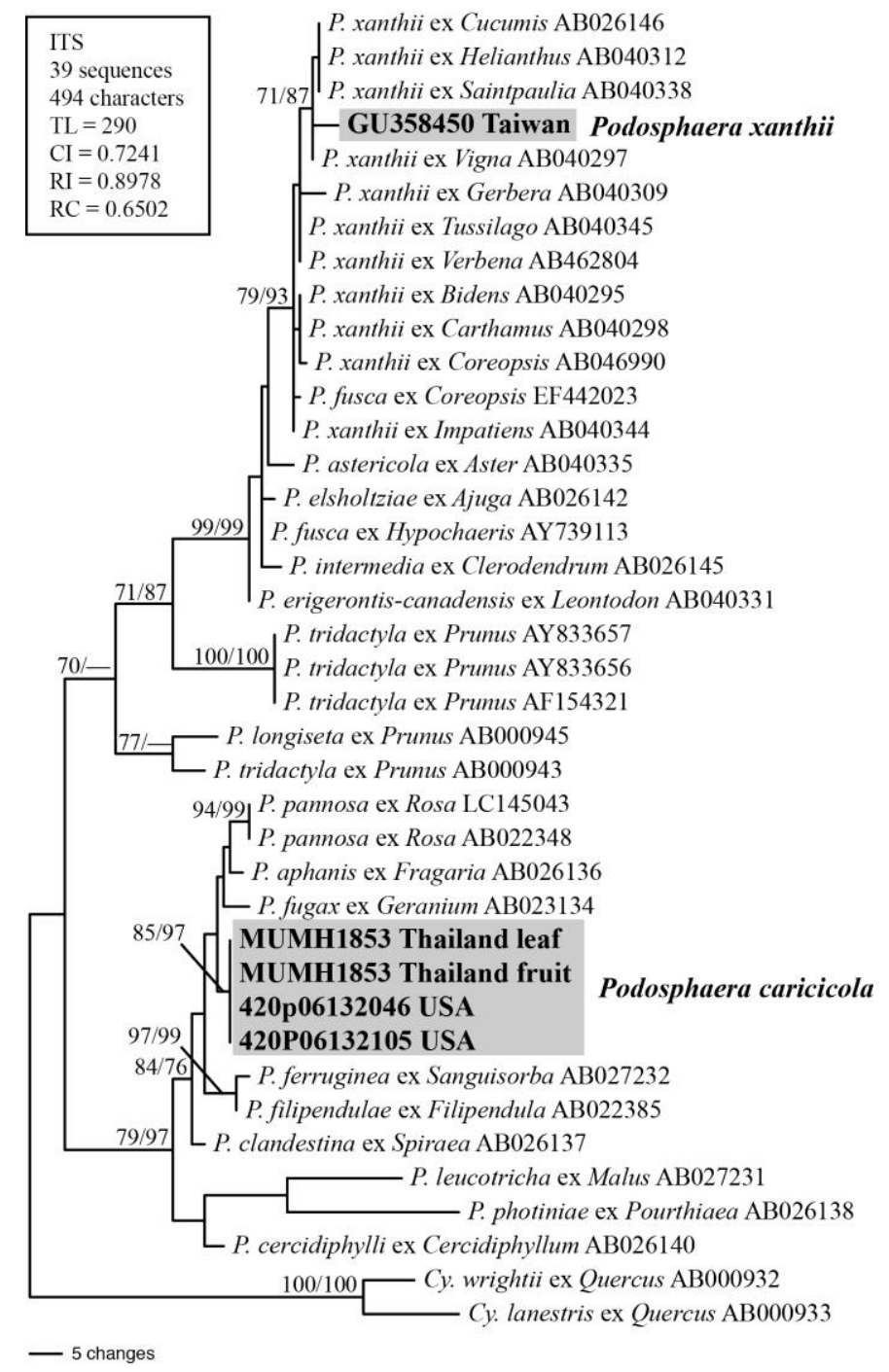

Figure 8 - Phylogenetic analysis of Podosphaera species on Carica papaya based on combined DNA sequences of internal transcribed spacer (ITS) region. This is one of the two equally parsimonious trees with 290 steps, which were found using a heuristic search. Horizontal branch lengths are proportional to the number of substitutions that were inferred to have occurred along a particular branch of the tree. BS $(\geq 70 \%)$ values by the maximum parsimony (MP) and maximum likelihood (ML) methods were shown on the respective branches.

Podosphaera xanthii (Castagne) U. Braun \& Shishkoff, Schlechtendalia 4: 31, 2000 (sect. Sphaerotheca subsect. Magnicellulatae) 1985.

= Sphaerotheca caricae-papayae Tanda \& U. Braun, Trans. Mycol. Soc. Japan 26: 316,

三Podosphaera caricae-papayae (Tanda \& U. Braun) U. Braun \& S. Takam., Schlechtendalia 4: 27, 2000.

Misapplied name: Oidium caricae auct. (Braun 1987).

Description of the sexual morph on papaya (based on a re-examination of holotype material): Chasmothecia scattered to gregarious, 91-109 $\mu \mathrm{m}$ diam; peridium cells conspicuous, large, 21-72 $\mu \mathrm{m}$ diam, shape irregularly polygonal; appendages few, in the lower half, mycelioid, simple or irregularly branched, often interwoven with each other and the mycelium, 50-110 $\times 5-8 \mu \mathrm{m}$, hyaline, later brown throughout or paler towards the tips, septate, walls thin, smooth to rough; ascus broad ellipsoid-ovoid to subglobose, 72-94 × 49-64 $\mu \mathrm{m}$, sessile or with a very short stalk, wall 3.8-5 $\mu \mathrm{m}$ thick, terminal oculus 15-20 $\mu \mathrm{m}$ diam, (6-) 8-spored; ascospores broad ellipsoidovoid to subglobose, $15-18 \times 10-12 \mu \mathrm{m}$, colorless. 
Material examined - Japan, Tokyo, Sakuragaoka, Setagaya-ku, on Carica papaya, 2 Dec. 1984, S. Tanda (holotype of Sphaerotheca caricae-papayae TUAMH 2779, isotype HAL 1460 F).

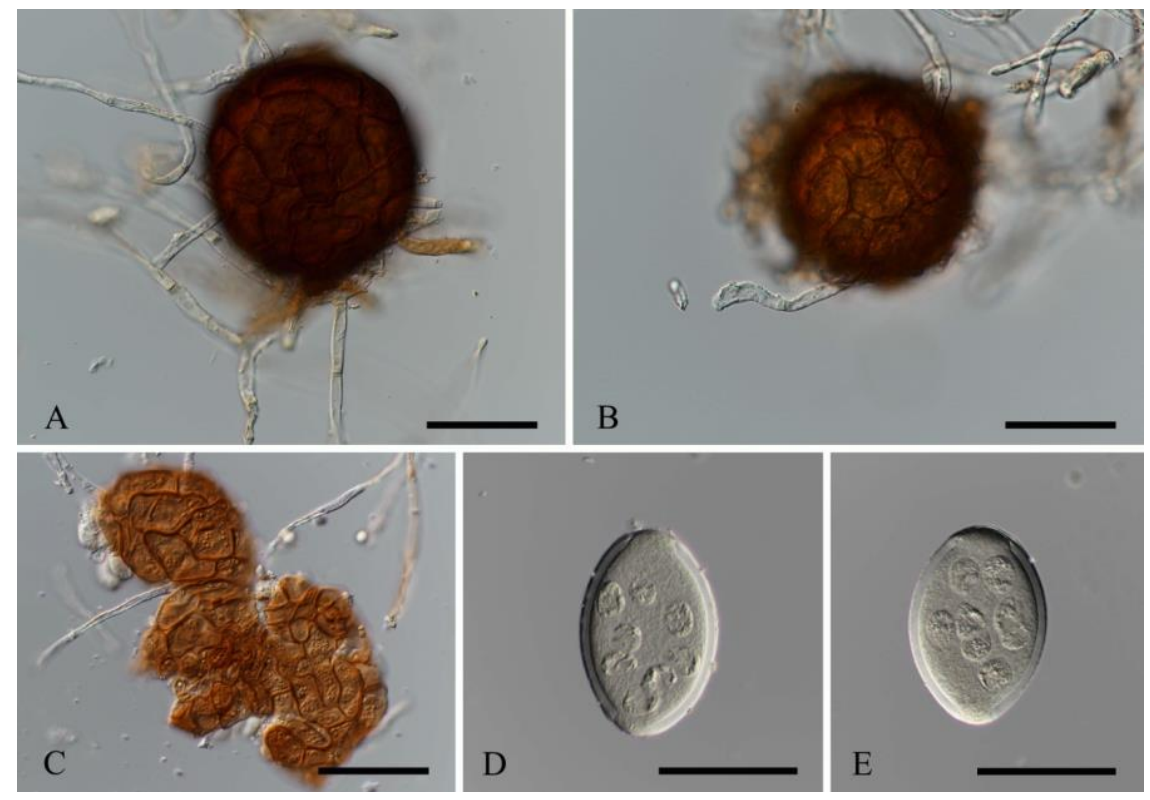

Figure 9 - Podosphaeara xanthii on Carica papaya. A-E TUAMH2779 (holotype of Sphaerotheca caricae-papayae). A, B Chasmothecium. C Peridium cells. D, E Asci. Bars $=50 \mu \mathrm{m}$.

Notes - Podosphaera xanthii is readily distinguishable from other papaya powdery mildews by forming catenescent conidia with distinct fibrosin bodies. The hyphal appressoria are unlobed (indistinct to nipple-shaped), and the chasmothecia are characterized by having large peridial cells, about 15-55 $\mu \mathrm{m}$ diam, and asci with large terminal oculi, (10-)15-25 $\mu \mathrm{m}$ diam. The asexual morph of this powdery mildew has previously been confused with Oidium caricae (e.g., in Braun 1987). Verma \& Sharma (1999: 483) emphasized that Oidium caricae, O. indicum, and Sphaerotheca fuliginea refer to a single species. Tanda \& Braun (1985) found fruiting bodies of this papaya powdery mildew and described it as Sphaerotheca caricae-papayae. The combination Podosphaera caricae-papayae was later introduced by Braun \& Takamatsu (2000). Braun \& Cook (2012) reduced this species to synonymy with the plurivorous $P$. xanthii, mainly based on the morphological similarity between the papaya Podosphaera and $P$. xanthii on cucumber and other hosts, as well as the report by Miller (1938) stating that papaya was infected in a greenhouse in California by "cucurbit powdery mildew". Chitambar (2015) emphasized that the synonymy of $P$. caricae-papayae and $P$. xanthii is unclear, unproven and in urgent need to be investigated further. Therefore, he maintained the name $P$. caricae-papayae, at least tentatively. The assignment of Podosphaera on papaya in Thailand to P. xanthii in Meeboon et al. (2016) was erroneous and refers to $P$. caricicola. However, a sequence recently retrieved from a powdery mildew collection of Podosphaera on papaya in Taiwan clusters within the large P. xanthii clade (Fig. 8) and supports the taxonomy of $P$. caricae-papayae proposed in Braun \& Cook (2012), including the reduction of the latter species to synonymy with $P$. xanthii, and should be maintained. Attempts to retrieve sequence data from type material of Sphaerotheca caricae-papayae were not possible due to the paucity of the material concerned. Braun \& Cook (2012) cited Oidium caricicola as synonym of $P$. xanthii, which is, however, doubtful (see notes under $O$. caricicola). The description of conidiophores and conidia of $O$. caricicola agrees well with $P$. xanthii, but the germ tubes illustrated in Yen \& Wang (1973) are in conflict with an interpretation of this species as $P$. xanthii since they are close to those of Podosphaera species of sect. Sphaerotheca subsect. Sphaerotheca. Based on available relatively reliable data and information, the distribution of $P$. xanthii on papaya can be summarized as follows: Australia, China, Cook Islands, India, Japan, New Zealand, Thailand, USA (Miller 1938, Alcorn 1968, Munjal \& Karpoor 1973, Dingley et al. 1981, Boesewinkel 1982b, Amano 1986, Braun 1987, Verma \& Sharma 1999, Paul \& Thakur 2006, 
Braun \& Cook 2012, Chitambar 2015, Meeboon et al. 2016, as "Sphaerotheca fuliginea", S. caricae-papayae, Podosphaera caricae-papayae or P. xanthii). Additional records of Sphaerotheca sp. on papaya from Australia (Shivas 1989), Hawaii (Raabe et al. 1981), and Ukraine (Dudka et al. 2004) might belong to $P$. xanthii as well, but they are unproven.

\section{Phyllactinia spp. on papaya}

Papaya is attacked by several species of the genus Phyllactinia, including Ovulariopsis (Braun \& Cook 2012). Takamatsu et al. (2016) carried out detailed phylogenetic analyses of a basal clade of Phyllactinia spp. comprising American species of this genus. Ovulariopsis caricicola U. Braun (三Streptopodium caricae Liberato \& R.W. Barreto) on papaya proved to be one of the species of this basal clade. Based on the current Code (ICN) and the new "one fungus one name" rule, the new combination Phyllactinia caricicola (U. Braun) Liberato, R.W. Barreto \& S. Takam. was introduced in this paper, along with formal reallocations of Ovulariopsis caricae Sawada and O. papayae Van der Byl to Phyllactinia, i.e. four Phyllactinia spp. are now known on papaya, viz. $P$. caricae (Sawada) U. Braun, P. caricicola, P. papayae (Van der Byl) U. Braun, and P. caricifolia Viégas. Descriptions and illustration are to be found in Braun \& Cook (2012). The relation between $P$. caricicola and $P$. caricifolia is unclear. It is possible that the two taxa belong to a single species. The two species have similar dimorphic conidia, but type material of $P$. caricifolia is insufficient for a final conclusion (Liberato et al. 2004, Braun \& Cook 2012).

\section{Excluded, doubtful and insufficiently known taxa described from or reported on papaya}

\section{Erysiphe cruciferarum Opiz ex L. Junell, Sv. Bot. Tidskr. 61(1): 217, 1967.}

Notes - Boesewinkel (1982b) carried out inoculation experiments with papaya powdery mildew and E. cruciferarum from wild radish (Raphanus raphanistrum) which was first transferred to Brassica napus. Later he managed to infect papaya in glass house experiments with $E$. cruciferarum, which led to his erroneous conclusion that $O$. caricae might be the "imperfect state" of E. cruciferarum. In the event that Boesewinkel (1982b) performed correct inoculation experiments, it cannot be excluded that E. cruciferarum was, indeed, able to cause infections on papaya in New Zealand. However, the occurrence of E. cruciferarum on papaya still needs to be studied using molecular methods.

Golovinomyces orontii (Castagne) Heluta, Ukrayins'k. Bot. Zhurn. 45(5): 63, 1988.

$\equiv$ Erysiphe orontii Castagne, Suppl. Cat. P1. Marseille: 52, 1851.

Misapplied name: Erysiphe cichoracearum (auct. p.p.).

Notes - Although unproven by means of inoculation experiments or results of molecular sequence analyses, it is possible that the plurivorous powdery mildew species $G$. orontii may infect papaya. Boesewinkel (1982b) found "Erysiphe cichoracearum" on papaya in New Zealand. Other records of "Erysiphe cichoracearum" from Mexico (Alvarez 1976, 1981) and Peru (Dongo \& Rocha 1968) might refer to G. orontii as well. Boesewinkel's (1982b) interpretation that the characteristics of Oidium caricicola are similar to "Erysiphe cichoracearum" is, however, doubtful since important details like the presence or absence of fibrosin bodies in the conidia are lacking in the original description. O. caricicola fits better to a species of Podosphaera sect. Sphaerotheca subsect. Sphaerotheca that also occurs on papaya (see Podosphaera caricicola).

\section{Leveillula taurica s. lat.}

Records of Leveilula taurica s. lat. on papaya are known from Australia, Malawi, Nigeria, Zambia, and Zimbabwe (Amano 1986, Peregrine \& Siddiqi 1972, Simmonds 1966, Whiteside 1966). However, first attempts have been made to split $L$. taurica s. lat. into smaller "units" (species) based on results of molecular sequence analyses and morphology (Braun \& Cook 2012). In the light of this new taxonomic approach, and due to lacking morphological details and sequence 
data of Leveillula on papaya, the powdery mildew concerned can currently only be referred to as Leveillula sp.

Oidium caricae-papayae J.M. Yen, Rev. Mycol. 31: 316, 1966.

Material examined - Taiwan, Nantou, on Carica papaya, 16 Mar. 1966, S.K. Sun (holotype PC0022110).

Notes - The name $O$. caricae-papayae has often been confused with $O$. caricae and considered to be a synonym of the latter species (Bappammal et al. 1995, Hosagoudar \& Agarwal 2009). Braun \& Cook (2012) listed O. caricae-papayae under "Anamorphic powdery mildews (Oidium) of unclear generic affinity" and provided a description. The hyphal appressoria are lobed, conidiophores are relatively broad, to $12 \mu \mathrm{m}$, and the conidia are formed in chains of 3 to 9 (catenescent). The combination of lobed appressoria and catenate conidia is unusual and mainly known from species of the genus Neoerysiphe. In Boesewinkel (1980), O. caricae-papayae was also keyed out under species with conidia formed in chains, and Boesewinkel (1982b) recognized it as a species of its own. Menzies \& Kempler (1991) described and illustrated "Oidium caricae-

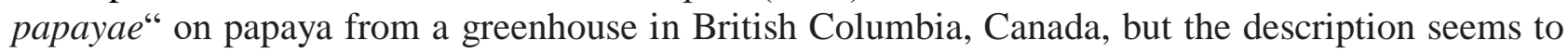
refer rather to the North American Erysiphe fallax, although conidia in short chains were mentioned. Chen \& Yang (2002) reported O. caricae-papayae on Eriobotrya japonica from China (Fujian), which is, however, unconfirmed and doubtful. The taxonomic status and generic affinity of $O$. caricae-papayae are quite unclear.

However, a careful analysis of Yen's (1966) publication and illustration suggests that his description was based on two species co-existing on papaya. A currently examined collection from Thailand (TSU-MUMH3383, HAL 3192 F) with a mixed infection of Podosphaera caricicola and Erysiphe caricae-papayae represents a similar striking case. Figs 1A (conidiophores with solitary conidia) and E (lobed appressoria) in Yen's (1966: 313) illustration seem to represent a Pseudoidium, whereas Fig. B (conidiophores with catenescent conidia) might belong to another species. Based on relatively short conidiophores, 36-55.2 $\times 8.4-12 \mu \mathrm{m}$, and doliiform conidia (Yen 1966: 313, Fig. D), the powdery mildew with catenate conidia might rather pertain to Podosphaera, either $P$. caricicola or $P$. xanthii. Germ tubes shown in Fig. F rather suggest $P$. caricicola. This is, of course, speculative and uncertain. Thus, it is better to treat $O$. caricae-papayae as an unclear, excluded species. If the name $O$. caricae-papayae was, indeed, based on two different elements (powdery mildew taxa), its application depends on a lectotypification. In this case, the name $O$. caricae-papayae should be confined to the Erysiphe element with lobed hyphal appressoria and conidia formed singly. However, since several Erysiphe spp. are known on papaya, the true identity of $O$. caricae-papayae remains unclear, pending results of molecular sequence analyses or epitypification.

Liberato et al. (2004) classified $O$. caricae-papayae as an invalid name due to lack of designation of type material, which is, however, not correct since Yen (1966) cited a single specimen that has to be considered holotype material according to ICN, Art. 9.1 (including Note 1). Art. 40.1 is fulfilled by the citation of a single collection examined, and Art. 40.6 cannot be applied since this article was not effective before 1 Jan 1990.

Oidium indicum Kamat, in Chiddarwar, Curr. Sci. 24(7): 240, 1955, nom. inval. (ICN, Art. 39.1).

Notes $-O$. indicum is an invalid name. The original description of this species is absolutely insufficient (hyphae 5-7.5 $\mu \mathrm{m}$ wide; conidia obovoid to barrel-shaped, 31.5-46.8 $\times 13.7-23.4 \mu \mathrm{m}$, formed in chains of 3 to 5). The conidiophores and the presence or absence of fibrosin bodies in conidia were not described. Based on the given details, it was impossible to assign this species to any of the powdery mildew genera. Yen (1966) examined type material of this species (IMI 60596) and provided a description and illustration (Yen 1966: 315, fig. 2) that clearly shows a Pseudoidium with lobed hyphal appressoria and conidia formed singly, 37.2-51.6 × 14.4-21.6 $\mu \mathrm{m}$. Yen \& Wang (1973) reported a powdery mildew sample collected from a papaya in Taiwan which agreed morphologically with Yen (1966) as O. caricae. Boesewinkel (1982b) considered $O$. 
indicum to be morphologically identical with $O$. caricae, probably due to the conidial size given in the original description and Yen's (1966) publication, although the conidia were described to be catenate. Verma \& Sharma (1999) regarded $O$. indicum and $O$. caricae as synonyms of Sphaerotheca fuliginea, and Braun \& Cook (2002) reduced $O$. indicum to synonymy with $O$. caricae-papayae. All interpretations of this name are, however, doubtful and speculative. Based on Yen's (1966) examination of type material, $O$. indicum seems to be an asexual morph of Erysiphe, however, given the numerous Erysiphe species on papaya, it is impossible to assign this name to any of the recognized species. Furthermore, the name $O$. indicum is invalid and must be excluded.

\section{Key to powdery mildew species on papaya (confirmed and unconfirmed species)}

1. Mycelium internal and external; conidiophores usually emerging through stomata; conidia relatively large, usually 40-80 $\mu \mathrm{m}$ long, on an average $>50 \mu \mathrm{m}$, dimorphic, with morphologically differentiated primary and secondary conidia; chasmothecia large, usually more than $150 \mu \mathrm{m}$ diam, appendages mycelioid, asci usually 2-spored Leveillula sp.

1. Mycelium external, conidiophores arising from superficial hyphae; conidia catenescent or solitary, smaller, on an average $<50 \mu \mathrm{m}$, not dimorphic; chasmothecia, when formed, smaller, < $150 \mu \mathrm{m}$ (Erysiphe, Golovinomyces, Podosphaera) or mycelium internal and external, but conidiophores consistently arising from external hyphae; chasmothecia also large, but with equatorial lanceolate appendages bulbous at the base and penicillate cells in the upper half (Phyllactinia)

2. Mycelium exclusively external; conidia catenescent or solitary, on an average $<50 \mu \mathrm{m}$ long, ellipsoid-ovoid, doliiform or \pm cylindrical; chasmothecia, when formed, with mycelioid appendages (Erysiphe, Golovinomyces, Podosphaera)

2. Mycelium internal and external; conidia large, on an average $>50 \mu \mathrm{m}$, uniformly clavate or dimorphic, clavate and lanceolate; chasmothecia when formed with equatorial lanceolate appendages bulbous at the base and penicillate cells in the upper half (Phyllactinia) ................ 9

3. Conidia formed in chains (catenescent); hyphal appressoria indistinct to nipple-shaped ............ 4

3. Conidia formed singly; hyphal appressoria lobed (Erysiphe) ............................................... 6

4. Conidia without fibrosin bodies (fresh collections), conidial chains with sinuate edge line; footcells of the conidiophores straight to often curved at the base; chasmothecia with several asci, mostly 2-spored Golovinomyces orontii

4. Conidia with fibrosin bodies (fresh collections), conidial chains with crenate edge line; foot-cells of the conidiophores straight at the base; chasmothecia with a single ascus, $6-8$-spored ........... 5

5. Conidiophore foot-cells 30-70(-100) $\mu \mathrm{m}$ long, cylindrical; conidia with short and stout, often even forked germ tubes, often lateral; chasmothecia with large peridial cells, $15-55 \mu \mathrm{m}$ diam

Podosphaera xanthii s. lat. (incl. P. caricae-papayae)

5. Conidiophore foot-cells $30-50 \mu \mathrm{m}$ long, cylindrical; conidia with simple germ tubes, cylindrical to filiform, terminal to lateral; chasmothecia with smaller peridial cells, 5-25(-30) $\mu \mathrm{m}$ diam, on an average $\leq 20 \mu \mathrm{m}$ Podosphaera caricicola

6. Conidiophores with sinuous to spirally twisted foot-cells ................................. Erysiphe necator

6. Conidiophores with straight foot-cells, at most occasionally curved or slightly sinuous ............. 7

7. Asexual and sexual morphs formed; conidia ellipsoid-ovoid to cylindrical, $25-60 \times 14-25 \mu \mathrm{m}$; hitherto only known from Asia and Europe

7. Only asexual morphs known, morphologically barely distinguishable from E. caricae and $E$. caricae-papayae, further identifications only possible by means of molecular sequence analyses; see also E. cruciferarum, E. diffusa, and E. fallax

8. Chasmothecia large, 103-185 $\mu \mathrm{m}$ diam, with 4-10(-15) appendages, and 4-9 asci; Asia (Taiwan, Thailand) ...................................................................... Erysiphe caricae-papayae

8. Chasmothecia smaller, (65-)85-125 $\mu \mathrm{m}$ diam, with numerous appendages (usually > 10), and only 3-5 asci; Europe Erysiphe caricae 
9. Conidia dimorphic, primary conidia lanceolate, apically pointed, secondary conidia clavate; South America Phyllactinia caricicola (and P. caricifolia)

9. Conidia uniformly clavate 9

10. Conidia apiculate; Asia Phyllactinia caricae

10. Conidia non-apiculate; Africa Phyllactinia papayae

\section{Discussion}

Carica papaya and other species of the genus Carica are hosts of numerous powdery mildews belonging to various genera, including some records that are probably classifiable as accidental infections. Some powdery mildew species described on papaya are insufficiently known and have been notoriously confused. Many of these species are reassessed in this work, while others are listed in the section of "Excluded, doubtful and insufficiently known taxa" which urgently require re-examinations of type material and molecular sequence analyses of new collections. In the interim, the names concerned should not be applied in order to avoid further confusion. Oidium caricae, which is probably the most misapplied name amongst powdery mildews on papaya, was especially problematic. This name has been applied to various papaya powdery mildew worldwide. The first published results of molecular sequence analyses of $O$. caricae-like powdery mildews suggested that different Erysiphe species were involved (Tsay et al. 2011, Takamatsu et al. 2015). Additional phylogenetic examinations of $O$. caricae-like powdery mildews, including a collection from Brazil, have been carried out to distinguish the complex of taxa involved. Results of the analyses showed that at least five different Erysiphe taxa are able to infect papaya, including E. caricae and E. caricae-papayae, currently the only species for which a sexual morph is known. O. caricae, described from Brazil, is reduced to synonymy with Erysiphe diffusa. Collections from Mexico and the USA proved to belong to a separate species, described as E. fallax sp. nov., which is possibly widespread in the native distribution area of papaya from southern Mexico to Costa Rica. This is, however, speculative and needs further studies in the natural range of papaya. Identifications of papaya infections by Erysiphe cruciferarum in New Zealand obtained in the course of inoculation experiment carried out by Boesewinkel (1982b) also need confirmation by means of molecular methods. Similar asexual powdery mildew morphs collected on papaya in Asia belong to different species, including Erysiphe diffusa and E. caricaepapayae. All asexual morphs on papaya belonging to Erysiphe spp., except for E. necator, are difficult to distinguish morphologically and must be confirmed by molecular sequence analyses. The present studies of Erysiphe spp. of papaya are preliminary. Relatively few samples have been analysed to be able to even speculate about the genuine distribution of the taxa involved. Further examinations and analyses of Erysiphe spp. on papaya collected from areas where papaya is native or widely grown are urgently needed. Sequences retrieved from papaya powdery mildews that pertain to Podosphaera are genetically not uniform and cluster in different places on the phylogenetic tree. They represent two different species, viz. $P$. xanthii (including $P$. caricaepapayae), belonging to sect. Sphaerotheca subsect. Magnicellulata, and $P$. caricicola, a species of Sphaerotheca subsect. Sphaerotheca. The currently available knowledge about the occurrence of the two Podosphaera spp. on papaya is still fragmentary but suggests a wide distribution.

\section{Acknowledgements}

We are much obliged to J.C. Dianese for donating the Brazilian powdery mildew specimen on Caryocar brasiliense.

\section{References}

Alcorn JL. 1968 - Cucurbit powdery mildew on papaya. Queensland Journal of Agriculture and Animal Sciences 25, 161-164.

Alvarez MG. 1976 - Primer catálogo de enfermedades de plantas Mexicanas. Fitofilo 71, 1-169.

Alvarez MG. 1981 - Enfermedades de la plantas en la República Mexicana. Limusa, México D.F. 
Amano (Hirata) K. 1986 - Host Range and Geographical Distribution of the Powdery Mildew Fungi. Japan Scientific Societies Press, Tokyo.

Baiswar P, Chandra S, Ngachan S. 2016 - Molecular evidence confirms presence of anamorph of Erysiphe diffusa on soybean (Glycine max) in northeast India. Australasian Plant Disease Notes 11, 25.

Bappammal M, Hosagoudar VB, Udaiyan K. 1995 - Powdery mildews of Tamil Nadu, India. New Botanist 22, 81-175.

Basu PK. 1980 - Occurrence of soybean foliage disease in eastern Ontario, 1979. Canadian Plant Disease Survey 60, 23-24.

Bensch K, Braun U, Groenewald JZ, Crous PW. 2012 - The genus Cladosporium. Studies in Mycology 72, 1-401.

Boesewinkel HJ. 1980 - The morphology of the imperfect states of powdery mildews (Erysiphaceae). Botanical Revue 46, 167-224.

Boesewinkel HJ. 1982a - Babaco, mountain papaya and papaya: all are susceptible to powdery mildew. New Zealand Journal of Agriculture 145, 28.

Boesewinkel HJ. 1982b - The identity of Oidium caricae and the first recording on papaya, mountain papaya and babaco in New Zealand. Fruits 37, 473-477.

Bolay A. 2005 - Les Oïdiums de Suisse (Erysiphacées). Cryptogamica Helvetica 20, 1-173.

Braun U. 1987 - A monograph of the Erysiphales (powdery mildews). Beihefte zur Nova Hedwigia $89,1-700$.

Braun U, Cook RTA. 2012 - Taxonomic Manual of the Erysiphales (Powdery Mildews). CBS Biodiversity Series No. 11, 1-707.

Braun U, Takamatsu S. 2000 - Phylogeny of Erysiphe, Microsphaera, Uncinula (Erysipheae) and Cystotheca, Podosphaera, Sphaerotheca (Cystotheceae) inferred from rDNA ITS sequences - some taxonomic consequences. Schlechtendalia 4, 1-33.

Burchill RT. 1978 - Powdery Mildews of Tree Crops. Pp. 473-493. In Spencer DM. [Ed.], The Powdery Mildews. Academic Press, London.

Cavalho FA. 2013 - e-Monograph of Caricaceae. Version 1, November 2013 [Database continuously updated]; http://herbaria.plants.ox.ac.uk/bol/Caricaceae.

Chen F-R, Yang X-J. 2002 - Investigation and identification of the fungal disease of Eriobiobotrya japonica in Fujian. Fujian Journal of Agricultural Sciences 17, 151-154.

Chitambar J. 2015 - Fungi, Plant Pathogens. Podosphaera caricae-papayae. California Pest rating. http://blogs.cdfa.ca.gov/Section3162/?p=1008

Cho WD, Shin HD. 2004 - List of plant diseases in Korea. Fourth edition. Korean Society of Plant Pathology.

Clare BG. 1964 - Erysiphaceae of south-eastern Queensland. Papers from the Department of Botany, University of Queensland 4, 111-144.

Crous PW, Phillips AJL, Baxter AP. 2000 - Phytopathogenic Fungi from South Africa. University of Stellenbosch, Department of Plant Pathology Press.

Cunnington B, Nelson S. 2012 - Powdery Mildew of Papaya in Hawai'i. Colleague of Tropical Agriculture and Human Resources, University of Hawai'i at Mānoa, Plant Disease, PD 90, 14.

Dingley JM, Fullerton RA, McKenzie EHC. 1981 - Survey of Agricultural Pests and Diseases. Technical Report Volume 2. Records of Fungi, Bacteria, Algae, and Angiosperms Pathogenic on Plants in Cook Islands, Fiji, Kiribati, Niue, Tonga, Tuvalu, and Western Samoa. F.A.O.

Dongo DS, Rocha de la GG. 1968 - Control químico de Oidium en frutales. Estacíon Experimental Agrícola de "La Molina", Boletim No. 22, 1-23.

Dudka IA, Heluta VP, Tykhonenko YY, Andrianova TV, Hayova VP et al. 2004 - Fungi of the Crimean Peninsula. M.G. Kholodny Institute of Botany. National Academy of Sciences of Ukraine.

Edgar RC. 2004 - MUSCLE: multiple sequence alignment with high accuracy and high throughput. Nucleic Acids Research 32, 1792-1797. 
Felsenstein J. 1985 - Confidence limits on phylogenetics: an approach using the bootstrap. Evolution 39, 783-791.

Fernández-Pavía SP, Gregorio-Cipriano R, Rodrígues-Alvarado G, Fernández-Pavia YL et al. 2015 - Enfermedades de Especies Vegetales en México. Editorio Morevalladolid, Morelia.

Fossard P. 1969 - Les maladies du papayer. Les maladies fongiques (Septième partie). Fruits 24, 473-482.

Freire FCO, Viana FMP. 2001 - Oídios de frutíferas tropicais. Pp. 323-334. In Stadnik MJ, Riveira MC [Eds], Oídios. Jaguariúna, SP.

Fu X-J, Liu S-Y, Jiang WT, Liu Y. 2015 - Erysiphe diffusa: a newly recognized powdery mildew pathogen of Wisteria sinensis. Plant Disease 99, 1272.

Gorter GJMA. 1993 - A revised list of South African Erysiphaceae (powdery mildews) and their host plants. South African Journal of Botany 59, 566-568.

Groenewald JZ, Nakashima C, Nishikawa J, Shin H-D, Park J-H, Jama AN, Groenewald M, Braun U, Crous PW. 2012 - Species concepts in Cercospora: spotting the weeds among roses. Studies in Mycology 75, 115-170.

Hirata T, Takamatsu S. 1996 - Nucleotide sequence diversity of rDNA internal transcribed spacers extracted from conidia and cleistothecia of several powdery mildew fungi. Mycoscience 37, $283-288$.

Hosagoudar VB, Agarwal DK. 2009 - Powdery mildews of India - check list. New Delhi.

Lehman SG. 1931 - Powdery mildew on soybean. Journal of the Elisha Mitchell Science Society 46, 190-195.

Lehman SG. 1947 - Powdery mildew on soybean. Phytopathology 37, 436.

Liberato JR, Barreto RW, Louro P. 2004 - Streptopododium caricae sp. nov., with a discussion of powdery mildews on papaya, and emended description of the genus Streptopodium and Oidium caricae. Mycological Research 108, 1185-1194.

McLaughlin MR, Mignucci JS, Milbrath CM. 1977 - Microsphaera diffusa, the perfect stage of the soybean powdery mildew pathogen. Phytopathology 67, 726-729.

McTaggart AR, Ryley MJ, Shivas RG. 2012 -First report of the powdery mildew Erysiphe diffusa on soybean in Australia. Australasian Plant Disease Notes 7, 127-129.

Meeboon J, Hidayat I, Takamatsu S. 2016 - Notes on powdery mildews (Erysiphaceae) in Thailand I. Podosphaera sect. Sphaerotheca. Plant Pathology \& Quarantine 6, 142-174.

Mendes MAS, Silva VL da, Dianese JC, Ferreira MASV, Santos CEN dos, Neto EG, Urben AF, Castro C. 1998 - Fungos em Plantas no Brasil. Brasília.

Menzies JG, Kempler C. 1991 - Powdery mildew of babaco at Agassiz, British Columbia. Canadian Plant Disease Survey 71, 43-46.

Mignucci JS, Chamberlain DW. 1978 - Interactions of Microsphaera diffusa with soybeans and other legumes. Phytopathology 68, 169-173.

Miller PA. 1938 - Cucurbit powdery mildew on Carica papaya. Phytopathology 28, 672.

Mori Y, Sato Y, Takamatsu S. 2000 - Evolutionary analysis of the powdery mildew fungi using nucleotide sequences of the nuclear ribosomal DNA. Mycologia 92, 74-93.

Munjal RL, Kapoor JN. 1973 - Carica papaya: a new host of Sphaerotheca fuliginea. Indian Phytopathology 26, 366-367.

Noack F. 1898 - Cogumelos parasitas das plantas de pomar, horta e jardim. Boletim do Instituto Agrónomico do Estado de São Paulo 9, 75-88.

Paul YS, Thakur K. 2006 - Indian Erysiphaceae. Scientific Publishers, Jodhpur, India.

Paxton JD, Rogers DP. 1974 - Powdery mildew on soybeans. Mycologia 66, 894-896.

Peregrine WTH, Siddiqi MA. 1972 - A revised and annotated list of plant diseases in Malawi. Phytopathological Papers 16, 1-51.

Raabe RD, Conners IL, Martinez AP. 1981 - Checklist of plant diseases in Hawaii. Colleague of Tropical Agriculture and Human Resources, University of Hawaii, Information Text no. 22, 1-313. 
Shivas RG. 1989 - Fungal and bacterial diseases of plants in Western Australia. Journal of the Royal Society of Western Australia 72, 1-62.

Silvestro D, Michalak I. 2012 - raxmlGUI: a graphical front-end for RAxML. Organisms Diversity \& Evolution 12, 335-337.

Simmonds JH. 1965 - Papaw diseases. Queensland Agricultural Journal 91, 666-677.

Simmonds JH. 1966 - Host index of plant diseases in Queensland. Brisbane.

Soldaña MH, Márques MM, Ruiz BP. 1985 - Identificación en enfermedades fungosas del cultivo de la papaya (Carica papaya L.) en el estado de Tabasco. Revista Mexicana de Fitopatologia $3,14-17$.

Swofford DL. 2002 - PAUP*: Phylogenetic Analysis Using Parsimony (*and Other Methods), 4.0b4a. Sinauer Associates, Sunderland, Massachusetts.

Takamatsu S, Kano Y. 2001 - PCR primers useful for nucleotide sequencing of rDNA of the powdery mildew fungi. Mycoscience 42, 135-139.

Takamatsu S, Shin HD, Urailak P, Limkaisang S et al. 2002 - Two Erysiphe species associated with recent outbreak of soybean powdery mildew: results of molecular phylogenetic analyses based on nuclear rDNA sequences. Mycoscience 43, 333-341

Takamatsu S, Ito (Arakawa) H, Shiroya Y, Kiss L, Heluta V. 2015 - First comprehensive phylogenetic analysis of the genus Erysiphe (Erysiphales, Erysiphaceae) I. The Microsphaera lineage. Mycologia 107, 475-498.

Takamatsu S, Siahaan SAS, Moreno-Rico O, Cabrera de Álvarez MG, Braun U. 2016 - Early evolution of endoparasitic group in powdery mildews: molecular phylogeny suggests missing link between Phyllactinia and Leveillula. Mycologia 108, 837-850.

Tamura K, Stecher G, Peterson D, Filipski A, Kumar S. 2013 - MEGA6: Molecular Evolutionary Genetics Analysis version 6.0. Molecular Biology and Evolution 30, 2725-2729.

Tanda S, Braun U. 1985 - Two new powdery mildew fungi on Carica papaya and Phyllanthus flexuosus. Transactions of the Mycological Society of Japan 26, 315-319.

Teixeira da Silva JA, Rashid Z, Nhut DT, Sivakumar D et al. 2007 - Papaya (Carica papaya L.) biology and technology. Tree and Forestry Science and Biotechnology 1, 47-73.

Tsay JG, Chen RS, Wang HL, Wang WL, Weng BC. 2011 - First report of powdery mildew caused by Erysiphe diffusa, Oidium neolycopersici, and Podosphaera xanthii on papaya in Taiwan. Plant Disease 95, 1188.

Van Overeem C, Schwarz MB. 1926 - Oidiaceae. Oidium caricae NOACK. Icones Fungorum Malyensium (Abbildungen und Beschreibungen der Malayischen Pilze) 16, 1-3 [4].

Verma LR, Sharma RC. 1999 - Diseases of Horticultural Crops: Fruits. New Delhi, Indus Publishing Company.

Wahl von C. 1921 - Schädlinge an der Sojabohne. Zeitschrift für Pflanzenkrankheiten 31, 194196.

Walsh SP, Metzger DA, Higuchi R. 1991 - Chelex 100 as a medium for simple extraction of DNA for PCR-based typing from forensic material. Biotechniques 10, 506-513.

Whiteside JO. 1966 - A revised list of plant diseases in Rhodesia. Kirkia 5, 87-196.

Yánez-Morales M de Jesus, Braun U, Minnis AM, Tovar-Pedraza JM. 2009 - Some new records and new species of powdery mildew fungi from Mexico. Schlechtendalia 19, 47-61.

Yen JM. 1966 - Étude sur les Champignons parasites du Sud-Est asiatique. VI : Un nouvel Oidium récolté à Taiwan (Formose) sur Carica papaya : Oidium caricae-papayae Yen (n. sp.). Revue Mycologie (Paris) 31, 311-316.

Yen JM, Wang CC. “1972” 1973 - Étude sur les champignons parasites du Sud-Est asiatique XXII : Les Oidium de Formose (II). Revue Mycologie (Paris) 37, 125-153. 